\title{
Dampak Hasil Pelatihan Kecakapan Hidup Bagi Pemuda Di Desa Paris
}

\author{
Gustin N. Igirisa ${ }^{1}$, Misran Rahman ${ }^{2}$, Rapi Us. Djuko ${ }^{3}$ \\ Jurusan Pendidikan Luar Sekolah, Fakultas Ilmu Pendidikan, Universitas Negeri Gorontalo \\ gustinigirisa6@gmail.com, misran@ung.ac.id,rapi.djuko@ung.ac.id
}

Received: 25 Mei 2021; Revised: 11 Desember 2021; Accepted: 13 Desember 2021

\begin{abstract}
This study aims to discover the Impact of Life Skill Training on Youth Unemployment in Paris Village, Mootilango Subdistrict. This study employs qualitative descriptive research with the data collection technique are observation, interview, and documentation. The findings concerning life skill training in Paris Village, Mootilango Subdistrict are as follows; first, the life skill training is highly beneficial and is needed by the youth who want to get a job or develop a business. Second, after participating in life skills training, the youth improvements include knowledge, attitudes, and skills that greatly support the training process. Third, life skill training indicates a positive impact, namely the youth can work both independently and in groups and use their skills or knowledge to start a business.
\end{abstract}

Keywords: Life skills, youth.

ABSTRAK
Penelitian ini bertujuan untuk mengetahui Dampak Hasil Pelatihan Kecakapan Hidup Bagi Pemuda Pengangguran di Desa Paris Kecamatan Mootilango. Jenis penelitian ini menggunakan penelitian kualitatif deskriptif, dan teknik pengumpulan data menggunakan teknik observasi, wawancara dan dokumentasi. Hasil penelitian yang didapatkan terkait dengan pelatihan kecakapan hidup di Desa Paris Kecamatan Mootilango sebagai berikut, pertama pelaksanaan pelatihan kecakapan hidup sangat bermanfaat dan dibutuhkan oleh pemuda yang ingin mendapatkan lapangan pekerjaan ataupun mengembangkan usahanya. Kedua setelah pemuda mengikuti pelatihan kecakapan hidup terjadi perubahan mencakup pengetahuan, sikap dan keterampilan yang sangat mendukung proses pelatihan. Ketiga dampak dari pelatihan kecakapan hidup menunjukkan dampak positif yaitu pemuda dapat bekerja secara mandiri dan berkelompok, memanfaatkan pengetahuan yang dimiliki untuk memperoleh usaha.

Kata kunci: Kecakapan hidup, pemuda.

(C2021 by (Gustin N. Igirisa, Misran Rahman, Rapi Us. Djuko) Under the license CC BY-SA 4.0

\section{PENDAHULUAN}

Direktorat pembinaan Kursus dan Pelatihan pada tahun 2012 telah memprogramkan, melanjutkan, dan memperkuat pelayanan pendidikan kecakapan hidup (life skill) bagi warga masyarakat yang putus sekolah, menganggur dan kurang mampu (miskin). Penyelenggaraan Program Pendidikan Kecakapan Hidup merupakan upaya nyata untuk mendidik dan melatih pemuda agar menguasai bidang-bidang keterampilan tertentu sesuai dengan kebutuhan, bakat minat, dan 
peluang kerja/usaha mandiri yang dapat di manfaatkan untuk bekerja baik di sektor formal maupun informal sesuai dengan peluang kerja atau usaha mandiri.

Dalam Kamil (2012:130) Kecakapan hidup adalah kemampuan, kesanggupan dan keterampilan yang diperlukan oleh seseorang untuk menjalankan kehidupan dengan nikmat dan bahagia.

Berdasarkan penjelasan diatas, maka dapat disimpulkan arti pentingnya pendidikan kecakapan hidup sebagai upaya membangun sikap kewirausahaan pemuda untuk masa depan. Melalui sistem pendidikan yang ada di Indonesia saat ini di harapkan dapat menerapkan pendidikan kecakapan hidup kepada pemudapemuda. Melalui pendidikan formal, informal maupun non formal. Melalui penelitian ini memfokuskan pemberian pelatihan kecakapan hidup untuk pemuda melalui pendidikan non formal.

Kreativitas pemuda dalam memanfaatkan barang bekas menjadi kerajinan tangan adalah solusi yang cukup baik untuk mengubah barang bekas menjadi barang yang berguna kembali, bahkan memiliki nilai jual serta dapat dikreasikan menjadi barang yang mempunyai nilai estetika. Kreativitas pemuda dapat ditumbuhkan melalui banyak cara, salah satunya yaitu dengan mengikuti pelatihan kecakapan hidup kerajinan tangan seperti membuat tempat duduk dari botol bekas dan lampu tidur dari pipa bekas. Adapun bahan yang digunakan banyak ditemui dilingkungan sekitar sehingga tidak memerlukan biaya besar hanya dengan bermodalkan keterampilan dalam memanfaatkannya.

Pelatihan mulai dilaksanakan sejak 25 februari 2019 berlangsung seminggu dua kali pertemuan satu pertemuan dilaksanakan 90 menit. Kegiatan pelatihan ini bertempat di Desa Paris Kecamatan Mootilango gedung yang disediakan oleh karang taruna, peserta yang mengikuti pelatihan ini sekitar 15 orang. Sebelum melakukan pelatihan tutor melakukan pendampingan secara intensif. Melakukan persiapan tempat, alat dan bahan sekaligus materi.

Dalam pemanfaatan barang bekas menjadi kerajinan tangan ini akan dilaksanakan melalui tahap : 
a. Sosialisasi Program

Sosialisasi program dilaksanakan setelah tahap persiapan selesai yaitu dengan melakukan pertemuan dengan peserta yang mengikuti pelatihan dan mensosialisasikan tentang program yang akan di laksanakan.

b. Penyampaian Materi

Pada tahap ini peserta akan diberikan materi seputar kewirausahaan, motivasi dan cara membuat kerajinan tangan dengan berbahan baku sampah plastik. Penyampaian materi menggunakan media power point. Materi diberikan oleh tutor yang diundang dari luar.

Kegiatan pelatihan kecakapan hidup yang dilakukan oleh kelompok pemuda bertujuan untuk menumbuhkan kreativitas dan sikap berwirausaha pemuda sehingga perekonomian pemuda akan lebih baik, Namun dari sisi lain persoalan yang sangat mendasar adalah setelah mengikuti pelatihan hasilnya belum terlihat jelas dengan beberapa faktor sehingga pemuda masih pengangguran dan belum memperlihatkan hasil-hasil yang mereka ikuti dalam pelatihan.

\section{METODE}

Penelitian ini menggunakan pendekatan kualitatif fenomenologis. Fenomenologi diartikan sebagai: 1) pengalaman subjektif atau pengalaman fenomenologikal. 2) suatu studi tentang kesadaran dari perspektif pokok dari seseorang (Husselr). Istilah fenomenologi sering di gunakan sebagai anggapan umum untuk menunjuk pada pengalaman subjektif dari berbagai jenis dan tipe subjek yang ditemui Moleong (2011:14-15).

Penelitian ini menggunakan jenis penelitian kualitatif yang bersifat interpretatif yaitu berusaha untuk mendapatkan data secara deskriptif dalam bentuk gejala tingkah laku dari orang yang diamati. Satori (2011: 23) mengungkapkan bahwa penelitian kualitatif dilakukan karena peneliti ingin mengeksplor fenomena-fenomena yang tidak dapat dikuantifikasikan yang bersifat deskriptif seperti proses suatu langkah kerja formula suatu resep, pengertian-pengertian tentang suatu konsep yang beragam karakteristik suatu 
barang dan jasa, gambar-gambar, gaya-gaya, tata cara suatu budaya, model fisik suatu artifak dan sebagainya.

Berdasarakan uraian diatas, dapat dikemukakan bahwa penelitian kualitatif yaitu suatu kegiatan dalam memperoleh data yang bersifat apa adanya dengan cara melakukan pengamatan secara langsung kegiatan pelatihan kecakapan hidup pemuda di Desa Paris. Maksud dari pemilihan subjek ini untuk mendapatkan sebanyak mungkin informasi dari berbagai macam sumber sehingga data yang diperoleh dapat diakui kebenarannya.

Pengumpulan data dilakukan dengan menggunakan metode observasi, wawancara, dan dokumentasi. Peneliti merupakan instrument utama dalam melakukan penelitian yang dibantu oleh pedoman observasi, pedoman wawancara, dan pedoman dokumentasi. Teknik yang digunakan dalam analisis data adalah display data, reduksi data, dan pengambilan kesimpulan.

\section{HASIL DAN PEMBAHASAN}

\section{Hasil}

Dari hasil penelitian kecakapan hidup bagi para pemuda di Desa Paris menunjukkan bahwa mereka telah memiliki keberanian dan sikap percaya diri dalam menjalankan usaha. Hal tersebut terlihat dengan adanya sebagian pemuda dapat membuat tempat duduk dari barang bekas. Dari sisi ekonomi telah meningkat dengan hasil penjualan yang mereka lakukan di pasar dan di jual secara online.

Perubahan sikap yang terjadi pada para pemuda setelah mengikuti pelatihan life skill mereka percaya diri dalam hal meningkatkan usaha. Selain itu kemampuan yang sudah dimiliki oleh pemuda mampu mendesain barang-barang bekas menjadi barang jadi yang dapat digunakan untuk keperluan rumah tangga.

Keterampilan yang sudah dimiliki oleh pemuda yaitu mereka sudah bisa membuat rangka kursi sofa, pemberian spont atau busa sampai ketahap pembungkusan kursi sofa agar dapat hasil yang sempurna.

Sikap-sikap keterampilan tersebut yang dimiliki oleh pemuda terlebih dalam hal memberikan teladan kepada pemuda yang masih kecil, sehingga untuk dapat 
membentuk sikap memberikan teladan dan memberikan kesempatan kepada pemuda yang sudah besar untuk belajar memberikan materi atau menyampaikan materi kepada adek tingkatnya. Selain melatih jiwa keterampilan hal tersebut juga dapat melatih kepercayaan diri pemuda.

Berdasarkan keterampilan yang di bangun pada pemuda yang di wawancarai sudah memiliki sikap tersebut, karena mereka sudah cukup lama mengikuti dan menjadi pemuda, tidak heran apabila mereka memiliki potensi yang lebih dari pemuda yang usia nya di bawah mereka. Perhatian dan dukungan dari mentor dan tutor serta fasilitas yang diberikan ikut adil dalam pembentukan sikap keterampilan kepada pemuda.

Adapun dampak negatif masih ada sebagian dari pemuda yang belum mampu mengembangkan usahanya, kemudian faktor lingkungan yang kurang mendukung kegiatan pengembangan keterampilan tersebut. Disamping itu dukungan dana sampai saat ini belum ada, kemudian alat-alat yang dibutuhkan masih sederhana.

\section{Pembahasan}

Berdasarkan data yang didapatkan dilapangan yaitu tentang dampak hasil pelatihan kecakapan hidup bagi pemuda. Pelaksanaan pelatihan kecakapan hidup ini dilakukan digedung yang telah disediakan oleh karang taruna di Desa Paris yang dapat dimanfaatkan secara optimal. Dengan adanya ketersediaan peralatan ini, diharapkan dapat memicu semangat pemuda untuk terus mengembangkan kreativitas dan kepeduliannya terhadap lingkungan. Pengetahuan, kelestarian lingkungan dan kreativitas merupakan hal yang menjadi basis program kegiatan ini.

Pemanfaatan kembali secara langsung misalnya dengan membuat produk baru yang berbahan baku limbah atau barang bekas. Botol plastik berasal dari kemasan minuman ringan mudah ditemukan karena jenis minuman tersebut banyak dijual di mana-mana.

Botol-botol plastik tersebut memiliki beragam ukuran dan warna yang memiliki nilai artistik dapat dimanfaatkan untuk membentuk benda-benda bernilai 
guna. Selain botol plastik, kerdus bekas, dan pipa bekas menjadi limbah yang banyak tersedia di lingkungan. Barang bekas tersebut sebenarnya merupakan sampah nonorganis yang tidak dapat terdaur ulang oleh alam, tetapi tetap menjadi limbah karena pemakaiannya yang banyak dan belum termanfaatkan.

Kegiatan pelatihan diikuti oleh para pemuda desa Paris. Peserta pelatihan ini berjumlah 15 orang, dengan rentang usia 18-35 tahun. Tingkat pendidikan para peserta adalah SMP dan SMA. Peserta meskipun dengan rentang usia cukup besar tetapi dengan tingkat pendidikan relatifsederajat ini memudahkan pelaksanaan pelatihan, karena terdapat kesamaan basis pengetahuan dan pengalaman dari peserta.

\section{SIMPULAN}

Data hasil penelitian yang didapatkan terkait dengan pelatihan kecakapan hidup di Desa Paris Kecamatan Mootilango adalah pelatihan kecakapan hidup yang tidak hanya memberikan keterampilan kepada pemuda pelatihan namun memberikan pengetahuan dan sikap yang menjadikan pemuda tersebut lebih baik. Seperti halnya pelatihan yang memberikan berbagai kegiatan yang berupa pembuatan Sofa dari botol bekas dan lampu hias dari pipa air. Namun dalam pelaksanaan dan proses pembelajaran, pemuda di berikan pelatihan dan pengetahuan untuk melatih para pemuda agar lebih percaya diri, mampu bersosialisasi, dan berkerjasama. Hasil dari perubahan sikap kewirausahaan yang sudah dimiliki pemuda setelah mengikuti pelatihan life skill adalah percaya diri dan berani dalam meningkatkan usaha. Faktor internal yang menghambat pemuda dalam ketidakberhasilan pelatihan life skill dalam membangun sikap kewirausahaan adalah sebagian pemuda terkendala oleh waktu dan jadwal pelatihan. Adapun faktor eksternal yang menghambat adalah: pertama sarana dan prasarana yang belum memadai dan jaringan untuk pemasaran produk hasil dari pelatihan kecakapan hidup (life skill) yang masih kurang sehingga belum ada pihak-pihak yang dapat menampung produk pemuda 


\section{DAFTARPUSTAKA}

Kamil, Mustofa. 2012. Model Pendidikan Dan Pelatihan ( Konsep Dan Aplikasi ). Bandung: Alfabeta

Moleong, Lexy J. 2006. Metodologi Penelitian Kualitatif. Bandung : PT Remaja Rosdakarya.

Satori, Djam'an. 2011. Metode Penelitian Kualitatif. Bandung: Alfabeta

Sugiyono. (2014). Metode Penelitian Pendidikan Kuantitatif, kualitatif dan R\&D. Bandung: Alfabeta 